\title{
VISUAL REPRESENTATION OF LAFFER CURVE FACTORING IN IMPLICATIONS OF CAPITAL OUTFLOW
}

\author{
Maria O. Kakaulina \\ Amur State University, Blagoveshchensk, Russia \\ ORCID: $\underline{0000-0002-2148-6236}$
}

\begin{abstract}
The article examines the problem of Laffer curve visualization. The purpose of the article is to propose a visual representation of the curve that takes into account the effects of capital outflow. The following research methods were used in the course of the research: historical method, comparative and critical analysis, graphical method. The author analyzes existing methods of the graphical representation of the curve drawin upon the interpretation of the original theoretical assumptions used for building a coordinate plane and taking into account additional factors (inflation, underground economy etc.). The author defines conditions for capital outflow and, as a result, for tax migration. The author proposes her own interpretation of the term "tax migration", listing the key reasons for its occurrence. A variant of Laffer curve visualization in different coordinate planes has been developed, factoring in tax migration. The obtained results made it possible to establish a range of permissible changes to tax rates within which government tax revenue increases. The time frame in which tax revenue grows is different, depending on the dynamics of the tax rates
\end{abstract}

\section{KEYWORDS}

Laffer curve; tax burden; tax revenue; tax migration; capital outflow; open economy; tax resident; graphical interpretation; income effect; substitution effect; tax "hysteresis"

\section{HIGHLIGHTS}

1. When carrying out tax reforms in a country, governments must start by empirically calculating a range of recommended changes to the tax burden, in this case tax policy might result in higher tax revenues

2. It is not expedient to reduce the tax burden unless there is a goal to encourage production rather than to earn more revenue for the treasury because in the future the concessions will by no means result in a matching increase in tax revenue

3. In order to use the Laffer curve as a tool of analysis it is necessary to specify the conditions for its application and its graphical representation in each case

\section{ВИЗУАЛИЗАЦИЯ КРИВОЙ ААФФЕРА С УЧЕТОМ ПОСАЕАСТВИЙ ОТТОКА КАПИТААА ЗА РУБЕЖ}

\section{М. О. Какаулина}

Амурский государственный университет, г. Благовещуенск, Россия ORCID: 0000-0002-2148-6236

\section{АННОТАЦИЯ}

Статья посвящена проблеме визуализации кривой Лаффера. Ее целью является предложение варианта визуализации кривой с учетом последствий оттока капитала за рубеж. В ходе исследования были применены такие методы науч- 
ного познания как исторический метод, сравнительный и критический анализ, графический метод. Проведен анализ существующих способов графического изображения кривой в зависимости от трактовки различных исходных теоретических допущений, используемой для построения координатной плоскости, учета в ходе анализа дополнительных факторов (инфляции, теневой экономики и др.). Были определены условия возникновения оттока капитала за рубеж и, как следствие, процесса налоговой «эмиграции». Предложена авторская трактовка понятия «налоговая «эмиграция», содержащая основные причины ее возникновения. Разработан вариант визуализации кривой Лаффера в различных координатных плоскостях с учетом фактора налоговой «эмиграции». Полученные результаты позволили установить интервал допустимых изменений уровня налоговой нагрузки, в пределах которого налоговые поступления в бюджет возрастают. Временной период роста налоговых доходов различается в зависимости от направления изменения налоговых ставок

\section{КЛЮЧЕВЫЕ СЛОВА}

Кривая Лаффера, налоговая нагрузка, налоговые поступления, налоговая «эмиграция», «бегство» капитала, экономика открытого типа, налоговый резидент, визуализация, эффект дохода, эффект замещения, налоговый «гистерезис»

\section{ОСНОВНЫЕ ПОЛОЖЕНИЯ}

1. При осуществлении налоговых преобразований в стране органам государственной власти необходимо предварительно определять интервал рекомендуемых значений изменения уровня налоговой нагрузки на основе эмпирических расчетов, в этом случае можно ожидать увеличения налоговых поступлений в бюджет

2. Снижать уровень налоговой нагрузки имеет смысл только в целях стимулирования производственной активности хозяйствующих субъектов, а не в целях пополнения бюджета страны, поскольку в будущем эти послабления ни при каких условиях не приведут к равноценному росту налоговых доходов

3. При применении в качестве инструмента анализа кривой Лаффера в каждом конкретном случае требуется уточнение условий ее использования и внешнего облика

\section{Introduction}

Can lower tax rates result in higher tax revenue for the government? The question has been repeatedly raised during tax policy debates in the USA and other developed and developing countries.

The relationship between the tax burden and the amount of tax revenue collected by the government is shown by the Laffer curve. Western scholars' interest in the concept has somewhat subsided recently due to its failed application in the course of Ronald Reagan's tax reform. Laffer's concept, however, boasts some success stories, for example, reforms by Presidents Harding and Coolidge and John Kennedy. In Russia, a successful example of the concept implementation was the introduction of a flat tax on individual income in 2001.

The hypothesis by Arthur Laffer about the influence of tax rates on the amount of the government's tax revenue is typically represented with an inverted U-shaped curve that crosses the horizontal axis at $0 \%$ and $100 \%$. Well-grounded and scientifically plausible theoretical interpretations of this particular shape of the curve are very scanty in the literature. It is the fragility of the original arguments and the extreme simplification of the justifications behind the curve shape that resulted in the emergence of more complex and modified variants of its graphical representation that take into account specific behavior of economic agents in response to changing tax rates in their domicile.

The task of elaborating the visual representation of the Laffer curve in relation to the current state of the economic system remains highly relevant today against the backdrop of constant societal development. 


\section{Literature review}

The current economic literature contains numerous graphical representations of the Laffer curve.

Among Russian scholars who worked on the subject are Iu. Sh. Ananiashvili, Ye. V. Balatsky, P. Yu. Buryak, A. S. Vetkin, V. P. Vishnevsky, V .P. Volobuyev, A. B. Gusev, D. V. Lipnitsky, S. L. Londar, I. A. Mayburov, T. V. Merkulova, S. M. Movshovich, V. G. Papava, V. P. Sinchak, A. V. Smorgonsky, L. Ye. Sokolovsky, S. G. Steshenko, I. Ya. Chugunov.

In the West, J. Buchanan., J. Wanniski, M. Gardner, P. Krugman, D. Lee, J. Malcomson, F. Gahvari, B. Dalamagas, and D. Henderson paid attention to the subject.

All papers on the subject can be divided into two groups: in group one, the shape of the Laffer curve is based on the analysis of its theoretical aspects (initial assumptions); in group 2 it is estimated empirically by constructing economic and mathematical models that set the type of the relationship between tax revenue and the tax burden.

A separate group comprises works by scholars who place the curve in an unconventional system of coordinates: "tax burden - time", or "tax burden - tax base".

An overwhelming majority of scholars belong to group two. They typically estimate certain parameters of the Laffer curve for a given economy, tax, time period, specific tax payers etc. by means of economic and mathematical modelling.

Group one is represented by A. Laffer, J. Wanniski, Ye. V. Balatsky, I. A. Maybu-

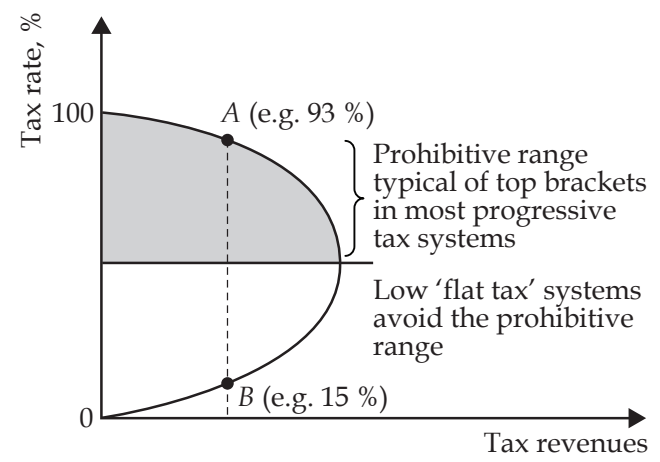

$a$ rov, V. G. Papava who provide substantial theoretical justifications for their graphical interpretation of the curve.

Despite the diversity of studies, none of the above mentioned authors take into account the influence of the international economic factor on the amount of tax revenue. They proceed from the assumption that a given economy exists in complete or partial isolation. In the real world, however, all national economies are involved in a single global economic system, and global economic cooperation has long since become an objective necessity along with steady economic growth.

It is therefore necessary to factor in the process of capital outflow and the resulting tax migration when analyzing the impact that changes to the tax burden have on tax revenue.

The purpose of this article is to develop a graphical interpretation of the Laffer curve that reflects the factor of tax migration.

\section{Historical analysis of variants of the graphical representation of the Laffer curve}

American economist Arthur Laffer originally sketched a curve of a relationship between tax revenue and rates of taxation on a napkin in 1974 (Figure 1a). Famous economist Jude Wanniski coined the name "Laffer curve" for the diagram. Four years later, Jude Wanniski presented what has become the classic depiction of the curve (Figure 1b).

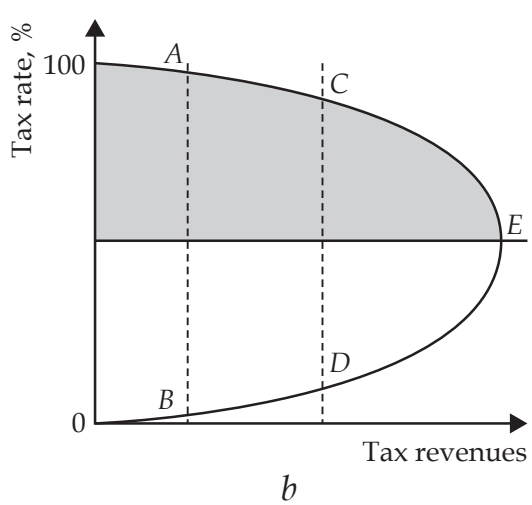

Figure 1. 'Classic' look of Laffer curve: a) by A. Laffer [1], b) by J. Wanniski [2] 
The features of the curve interpretation by Wanniski and Laffer himself is that it peaks symmetrically and its variables are placed unconventionally, with its independent variable lying on the vertical axis and the dependent variable on the horizontal axis.

Various scientists later proved that the classic Laffer curve was a sufficiently accurate representation of the behavior of economic agents in the case of personal income taxation. When it comes to other taxes, there are problems with establishing the end-points (where the curve crosses the horizontal axis). For example, the end-points for corporate income tax or value added tax will not match the initial assumption. The fact was demonstrated by Movshovich and Sokolovsky [3]. Consequently, the Laffer curve can be drawn as in Figure 2.

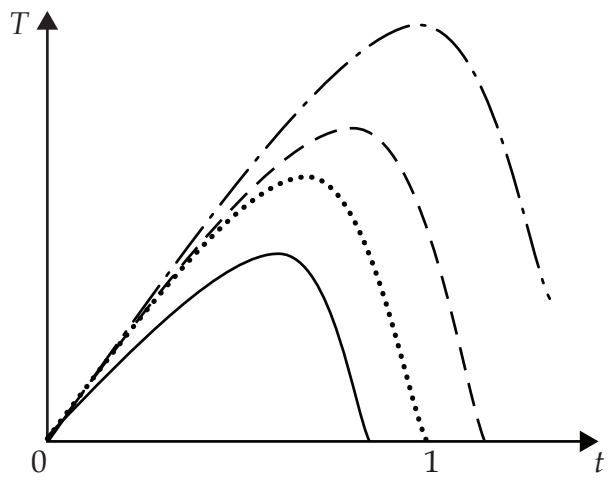

Figure 2. Graphical representation of Laffer curve considering end-point conditions [4]

Depending on additional revenueinfluencing factors being taking into account, the curve might show more asymmetry in both directions. Peter Gutmann visualized the dependence with the consideration of the underground economy. Gutmann's variant of the curve is strongly skewed to the right [5]. A large number of skewed bell-shaped curves that reflect the number of economic agents engaged in the economy can be found in the works by Smorgonsky.

Zsolt Besci considers various types of shifts in the Laffer curve depending on expenditure alternatives for the sake of balancing the budget. For example, when public investment is undertaken in order to balance the budget, the Laffer curve will be above the Laffer curve for private investment. When public consumption is used for balancing the budget, the Laffer curve will lie still further above the Laffer curve for public investment. Consequently, there are three revenue-maximizing tax rates when three alternative spending arrangements are available (Figure 3 ).

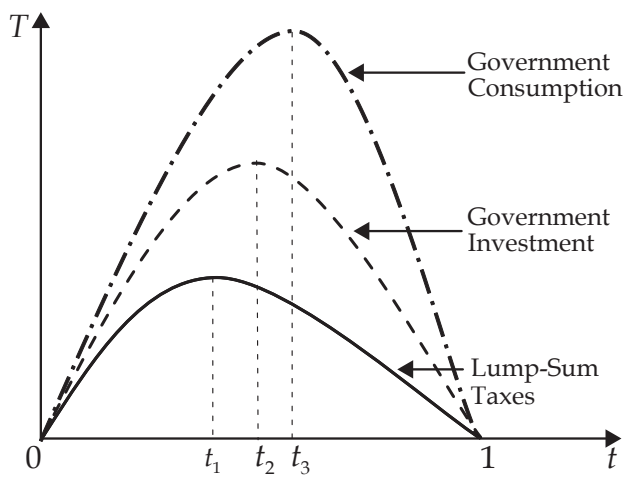

Figure 3. Laffer Curves under alternative spending arrangements [6]

The following graphic interpretations of the Laffer curve originate from a premise that it can have more than one inflection point. Henderson was the first one to observe that the amount of tax revenues could vary depending on people's preferences in case of lower taxes on labor income. Their reactions are not identical and are not predictable: some will work harder and find a side job (the income effect), others will give priority to leisure (the substitution effect). As we showed earlier, the income effect that reflects the stimulatory function of taxes can manifest itself on both the upward and downward sloping portions of the curve [7, p. 29]. People's preferences are determined by numerous associated factors: job complexity, family status, gender, age, educational background and income level.

Since the income effect and the substitution effect differ in absolute values, signs and the elasticity of taxable income in relation to labor income tax rates, their sum total might change from negative to positive several times in line with the reduction of the tax rate (Figure $4 a$ ). 


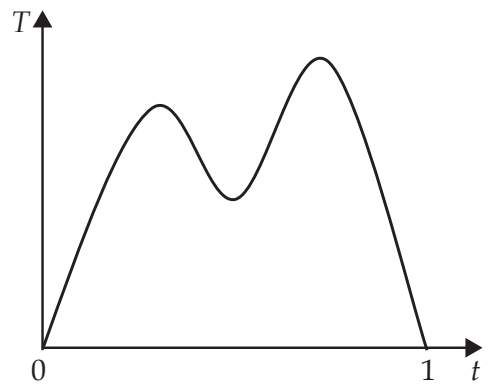

$a$

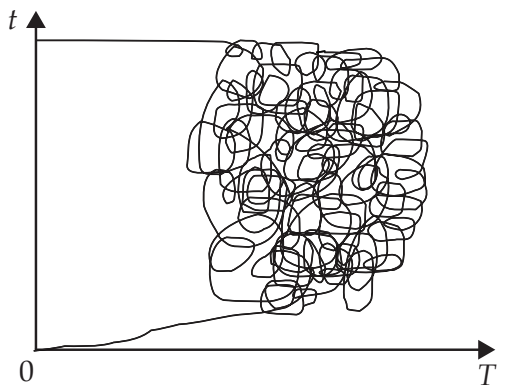

$b$

Figure 4. Graphical representations of Laffer curves with several inflection points: a) Henderson's version [8], b) Gardner's version [9]

Foreign scholars studying the Laffer curve obtained different estimates for the elasticity depending on the combination of factors included in the analysis, the time of the study and the sampling of taxpayers (Table).

Due to the variability of the obtained elasticity estimates, prominent mathematician Gardner suggested that the Laffer curve should be drawn as in Figure $4 b$.

By contrast to multiple peaks, some papers describe Laffer curves without an inflection point. Since the end-point condition of the curve - tax revenues becoming zero at the tax rate of $0 \%$ and $100 \%-$ is rarely satisfied, there might be situations when the dependence is described by an ever-ascending function without an optimum. For example, Russian scientist Ye. V. Balatsky attributed the deformation of the Laffer curve to rising inflation in the economy. When there is a strong inflation surge, the Laffer curve is characterized by an infinite growth (Figure 5).

\section{The results of elasticity of taxable income at income tax rate}

\begin{tabular}{|l|l|l|}
\hline \multicolumn{1}{|c|}{ Author } & \multicolumn{1}{|c|}{ Source data } & \multicolumn{1}{c|}{ Summary of Results } \\
\hline $\begin{array}{l}\text { Canto Joines, } \\
\text { (1981) }\end{array}$ & $\begin{array}{l}\text { Dependent Variable: Income Tax } \\
\text { Revenue } \\
\text { Key Independent Variable: In- } \\
\text { come Tax Rates } \\
\text { Years Covered: 1951-1964 } \\
\text { Unit of Analysis: Group (all tax- } \\
\text { payers in time series data sets) }\end{array}$ & $\begin{array}{l}\text { Through their regression simulation, the } \\
\text { authors find that in the years following 1964, } \\
\text { decreasing tax rates could raise tax revenue. } \\
\text { This points to the presence of the Laffer curve } \\
\text { during this time period and implies that the } \\
\text { U.S. was on the right side of this curve }\end{array}$ \\
\hline $\begin{array}{l}\text { Lindsey } \\
\text { (1987) }\end{array}$ & $\begin{array}{l}\text { Incomendent Variable: Taxable } \\
\text { Key Independent Variable: Top } \\
\text { marginal income tax rate } \\
\text { Years Covered: 1980-1984 } \\
\text { Unit of Analysis: Group (all tax- } \\
\text { payers in cross sectional data sets) }\end{array}$ & $\begin{array}{l}\text { The author obtains elasticity estimates of } \\
\text { 1.6 to 1.8 for the elasticity of taxable income } \\
\text { with respect to the top marginal tax rate. The } \\
\text { greatest responsiveness to tax rate changes } \\
\text { in high income earners. The U.S. is on the } \\
\text { right side of the Laffer curve during this } \\
\text { time period because the tax cuts are associ- } \\
\text { ated with an increase in tax revenue }\end{array}$ \\
\hline $\begin{array}{l}\text { Feldstein } \\
(1995)\end{array}$ & $\begin{array}{l}\text { Dependent Variable: Taxable } \\
\text { Income } \\
\text { Years Covered: 1985 and 1988 } \\
\text { Key Independent Variable: Top } \\
\text { marginal income tax rate } \\
\text { Unit of Analysis: Group (taxpay- } \\
\text { ers in the specific panel data set) }\end{array}$ & $\begin{array}{l}\text { Creates elasticity estimates of 1.04 to 3.05 for } \\
\text { the elasticity of taxable income with respect } \\
\text { to the marginal tax rate. Author also finds } \\
\text { increased tax rate responsiveness in high } \\
\text { income earners. These elasticities show that } \\
\text { the U.S. is on the right side of the Laffer } \\
\text { curve during this time period. The author } \\
\text { predicts that the 1993 tax increases should } \\
\text { only marginally increase tax revenue }\end{array}$ \\
\hline
\end{tabular}


End of the Table

\begin{tabular}{|l|l|l|}
\hline \multicolumn{1}{|c|}{ Author } & \multicolumn{1}{|c|}{ Source data } & \multicolumn{1}{c|}{ Summary of Results } \\
\hline $\begin{array}{l}\text { Goolsbee } \\
\text { (1999) }\end{array}$ & $\begin{array}{l}\text { Dependent Variable: Taxable } \\
\text { Income } \\
\text { Key Independent Variable: Top } \\
\text { marginal income tax rate } \\
\text { Years Covered: 1922-1926, 1931- } \\
\text { 1938, 1948-1952, 1962-1966 } \\
\text { Unit of Analysis: Group (all tax- } \\
\text { payers in cross sectional data sets) }\end{array}$ & $\begin{array}{l}\text { Creates elasticity estimates of 0.0 to 0.7 for the } \\
\text { elasticity of taxable income with respect to the } \\
\text { top marginal tax rate. These findings do not } \\
\text { show any evidence of a Laffer curve in the } \\
\text { U.S. during these time periods. These elastici- } \\
\text { ties show that the percentage decrease in tax- } \\
\text { able income after a tax increase will not be as } \\
\text { large as a one percent increase in the tax rate. } \\
\text { This shows that tax revenue will still increase } \\
\text { if tax rates increase. Author discounts the } \\
\text { notion that lowering tax rates could increase } \\
\text { tax revenue }\end{array}$ \\
\hline Saez (2004) & $\begin{array}{l}\text { Dependent Variable: Income } \\
\text { share of top decile of income earn- } \\
\text { ers (multiple groups of } \\
\text { income shares were used) } \\
\text { Key Independent } \\
\text { Variables: Top marginal tax rates } \\
\text { Time trends to control for exog- } \\
\text { enous factors that affect taxable } \\
\text { income } \\
\text { Years Covered: } 1960-2000 \\
\text { Unit of Analysis: Individual (tax } \\
\text { unit) }\end{array}$ & $\begin{array}{l}\text { Produces long-term elasticity estimates of } \\
\text { o.6-0.7 for the elasticity of the top 1\% income } \\
\text { share with respect to the top marginal tax rate. } \\
\text { Author only finds tax rate responsiveness in } \\
\text { the top 1 \% of income earners. These findings } \\
\text { also do not show evidence of the Laffer curve } \\
\text { because the elasticities are less than one. The } \\
\text { elasticities show that the percentage decrease } \\
\text { in the top 1 \% income share after a tax increase } \\
\text { will not be as large as a one percent increase } \\
\text { in the tax rate. This shows that tax revenue } \\
\text { will still increase if tax rates increase. Author } \\
\text { does not find evidence that there are negative } \\
\text { revenue effects of tax rate increases }\end{array}$ \\
\hline
\end{tabular}

Source: [10].

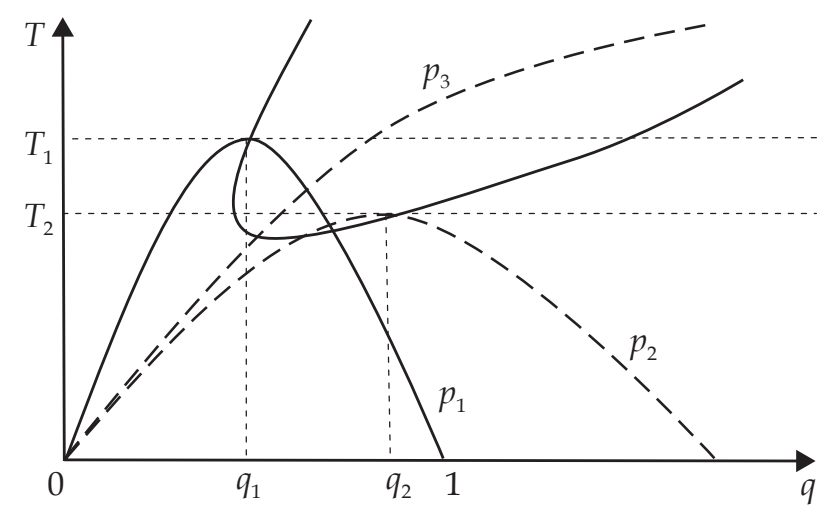

Figure 5. Graphical representation of Laffer curve without an inflection point [11]

A number of Laffer curve representation ideas are built upon research into the effect that changing tax rates have on the size of the tax base. That added an additional coordinate to the diagram - "tax base".

A substantial difference in the interpretation of the extended graphic representation of the curve by Laffer himself and by Russian scholars lies in the nature of its monotonicity. Laffer's version of the curve is inverted, while in the Russianlanguage literature it is usually drawn as convex (Figure 6).

In addition to the traditional fiscal Laffer curve for taxes, Balatsky also distinguishes the Laffer curve for production that graphically depicts a relationship between the tax burden and the tax base. Balatsky refers to the space between the taxation curve and the production curve as the "area of fiscal controversies" (Figure 7a). 

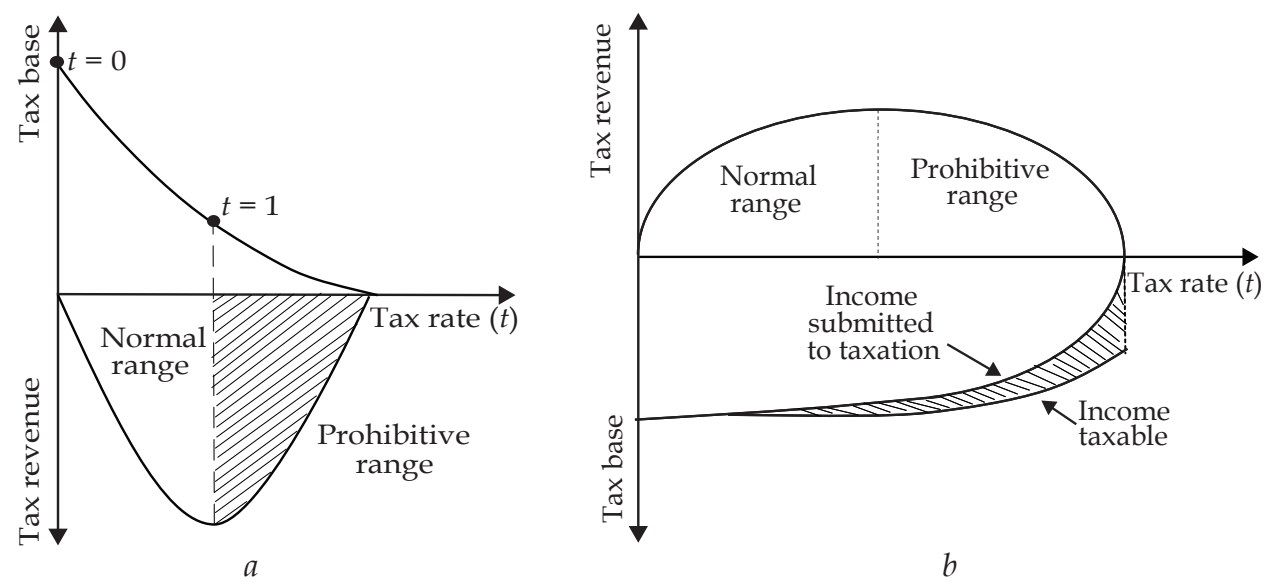

Figure 6. Extended Laffer curve:

a) Laffer's version [12], b) Volobuyev's version [13]

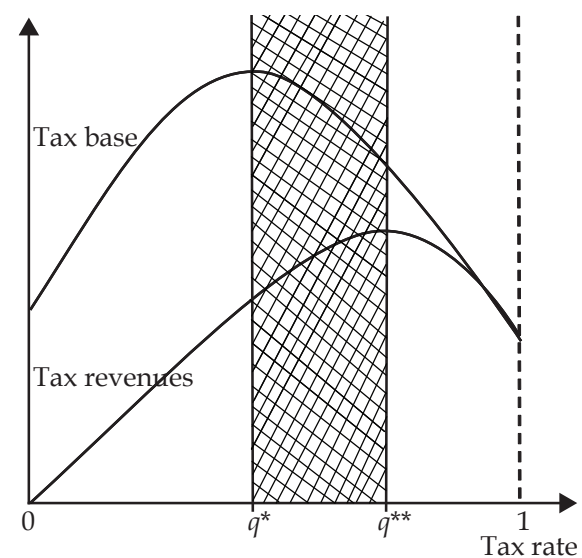

$a$

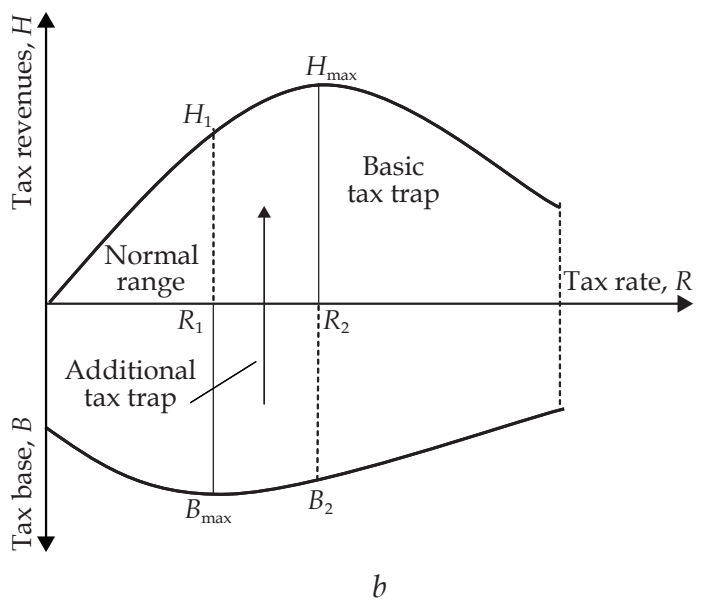

Figure 7. Graphical representation of fiscal and production Laffer curves: a) by Balatsky [14], b) by Mayburov [15]

I. A. Mayburov puts the curves in more conventional coordinates and introduces the concept of basic and additional "tax traps" (Figure 7b).

For the purpose of describing the dynamic processes that occur during the transformation of the tax burden, an attempt was made to draw the Laffer curve in the coordinate system of "tax revenues - time".

The first attempt to factor in time when drawing the Laffer curve was made by J. M. Buchanan and D. R. Lee (Figure 8).

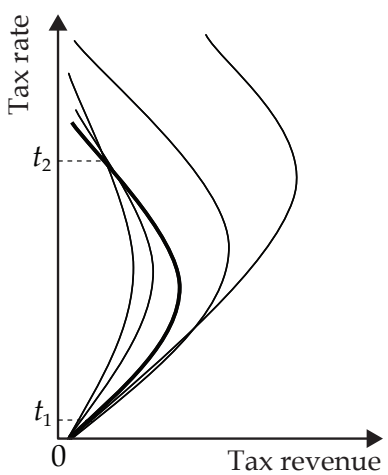

Figure 8. Graphical representation of Laffer curve with time factor [16] 
On the basis of their analysis of the enhanced curve the authors come to an important conclusion: higher tax rates will result in an increase in tax revenue in the short run, whereas lower tax rates will also drive up tax revenue, albeit in the long run.

Buryak and Londar also suppose that lower taxes will initially result in a shortterm drop in tax revenue, followed by an exponential growth in thanks to expansion of the tax base (Figure 9a).

A similar viewpoint can be found in Vishnevsky and Lipnitsky, one difference being that in some cases revenue shortfalls will never be replaced, that is, the period of tax revenue recovery is infinite [18].

In 2009, German economists V. G. Papava and Iu. Sh. Ananiashvili suggested drawing the Laffer curve in a three-dimensional coordinate system of "tax burden tax revenues - time". When constructing the curve in the three-dimensional space, the authors were guided by works of Balatsky, Vishnevsky and Lipnitsky. The addition of new curves was driven by the need to illustrate the Laffer Effect with fiscal "hysteresis" that characterizes a delay in the start of the growth of tax revenues in the wake of tax reduction (Figure 10).

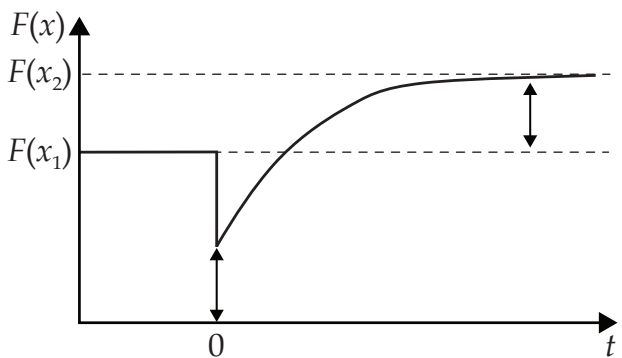

$a$

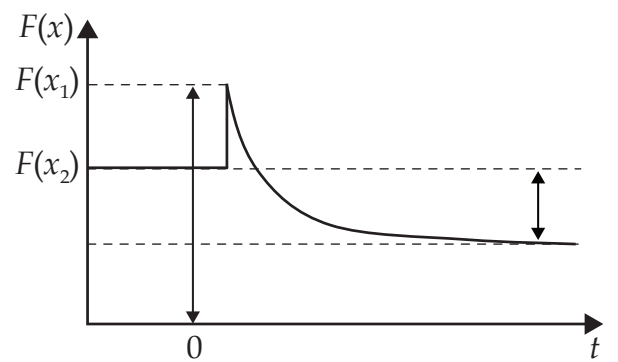

$b$

Figure 9. Graphical representation of Laffer curve in "tax revenues - time" coordinates in the case of: a) lower tax rates, b) higher tax rates [17]
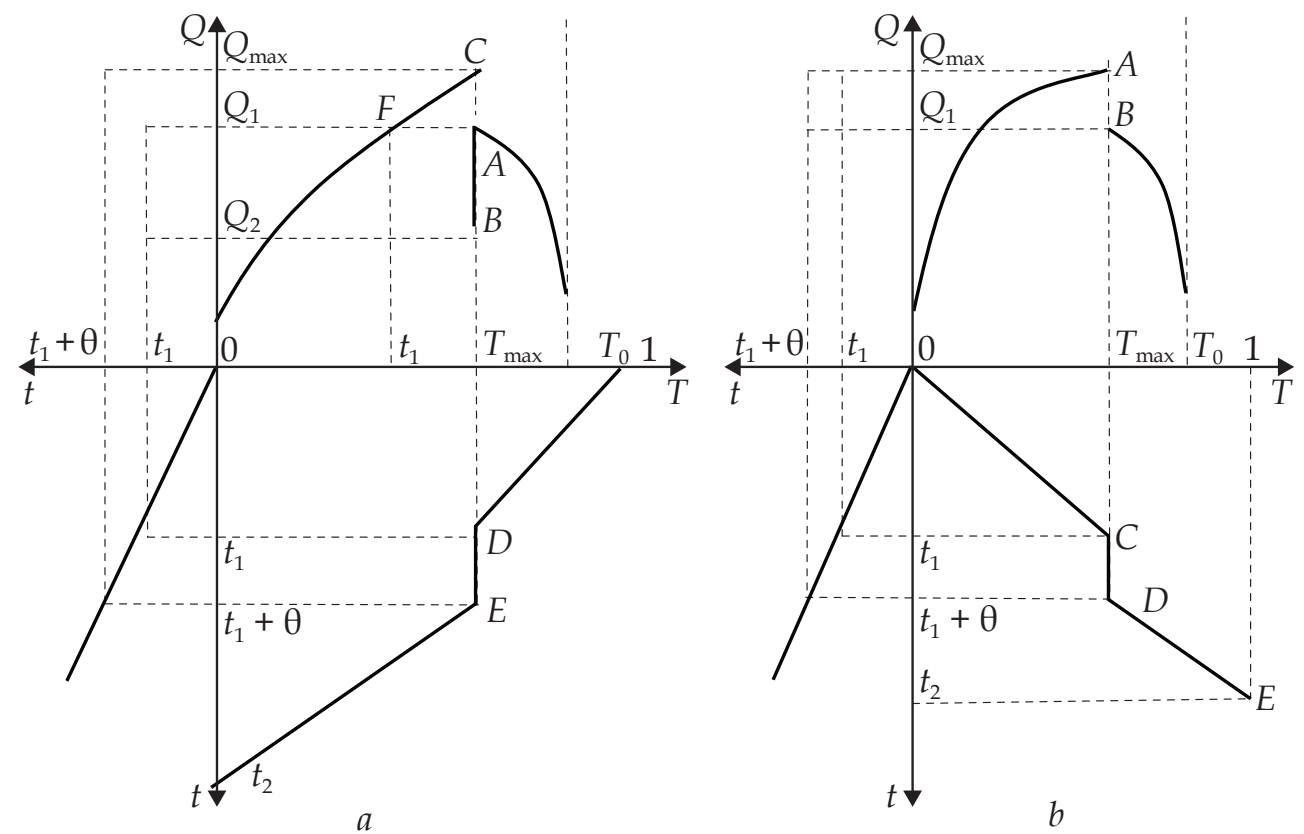

Figure 10. Graphical representation of Laffer curve in three-dimensional system by: a) Balatsky, b) Vishnevsky, Lipnitsky [19] 
Apart from the visual representations of the Laffer curve reviewed above, there are plenty of other variants proposed by other scholars.

\section{Tax migration and its causes}

It is commonly known that individual income taxes and corporate income taxes are the main sources of tax revenues in a country.

Consumption, saving and investment are the three main ways for economic agents to spend their income and profits [20].

In some cases, the income of citizens and businesses can be used as a resource for paying taxes both domestically and abroad. For example, this happens when:

- final consumption expenditure occurs abroad (individuals buy foodstuffs and non-food products and pay for services when travelling abroad);

- funds are saved abroad (by placing money on deposits in foreign banks);

- money is invested abroad (by buying property and vehicles, shares and bonds issued by foreign companies);

- a Russian organization opens a branch abroad.

When Russian nationals buy goods or services abroad, they pay indirect taxes as the taxes are included in the price.

When opening a savings account in a foreign bank, a Russian national has the right to pay taxes on interest income abroad if there is a double taxation avoidance agreement. A similar situation occurs when an individual receives dividends from shares in foreign companies or interest income from bonds.

Double taxation treaties unambiguously state that property taxes and capital gains from alienation (sale) or use (lease) of a property are to be paid in the country where it is located regardless of the tax payer's (owner's) country of residence) ${ }^{1}$.

Under double taxation treaties, business profits of a Russian company's subsidiaries abroad are taxed in the country where they are situated.

${ }^{1}$ Article 232 of Tax Code of the Russian Federation (as of March 2017 г.). Available at: http://www.consultant. ru/popular/nalog1/
A branch of a Russian company can pay VAT directly to the treasury of the country where it is located if it has taxpayer status. If the branch is not registered as a taxpayer, VAT can be withheld and transferred to the foreign state by a tax agent.

By paying the above taxes abroad, a Russia tax resident does not usually become exempt from paying the missing taxes to the Russian budget.

Eighty-two countries have signed double taxation treaties with Russia.

By signing the treaties, Russia suffers a loss of tax revenue due to tax "migration" to other countries and, as a result, has a certain amount of its financial resources withdrawn for the benefit of foreign economies.

That being said, we suggest that tax migration should be defined as a process whereby individuals and businesses that reside or are headquartered in Russia pay taxes to a foreign country by buying goods and services, securities, opening bank accounts, buying real estate there, leasing it out or establishing an office in the territory of a foreign state.

\section{Visual representation of the Laffer curve included tax migration factor}

When reviewing graphical representations of the Laffer curve, we came to a conclusion that the authors usually ignored foreign economic factors, assuming that the Russian economy exists in isolation. When modelling and constructing the curve, it is assumed that all resources of economic agents that become available thanks to lower tax rates will be part of the country's gross domestic product (GDP) and will subsequently be used for increasing the government's tax revenue.

In the real world, though, nearly all national economies are open, so we can observe an increase in the outflow of capital abroad when tax rates go down. In other words, when economic agents see their financial capability expand, they aspire to have holidays abroad, buy foreign-made goods or property abroad. Some of them intend to earn extra income by purchasing 
foreign securities or conducting business abroad. When they have more cash in the hand, the desire to make money abroad grows stronger.

The Laffer curve that is put in the coordinate system of "tax revenues - time" illustrates the above described reaction of economic agents (Figure 11).

When tax rates have been lowered, government bodies instantly notice a temporary decrease in tax revenues because the tax base remains the same. At a certain time point, tax revenues start to grow upon reaching a certain level $\left(T_{2}\right)$ thanks to the expanding tax base, but they will never match the previous level $\left(T_{1}\right)$ and will stay far below (at $T_{3}$ ) because of capital outflow. The difference between the initial level and the end level $\left(T_{1}-T_{3}\right)$ is the revenue shortfall caused by tax migration (Figure 11).
When the Laffer curve is drawn in the conventional coordinate system of "tax revenues - tax burden", the effect of tax "outflow" that occurs at lower tax rates can be depicted (Figure 12).

It is assumed that the economy of a country is at point $A$. Starting at point $A$, it is possible to move up and down the curve depending on changes to tax rates. The resulting Laffer curve has two rather than one inflection points, the first one indicating a critical level that the tax burden can be lowered to when the tax policy takes a more liberal turn $\left(t_{2}\right)$. The second inflection point indicates a critical level beyond which it is inexpedient to increase taxes when the national tax policy becomes tougher $\left(t_{3}\right)$. Tax revenues will start to shrink irrevocably outside the corridor marked by the recommended tax rates $\left(t_{2}, t_{3}\right)$ (Figure 12).

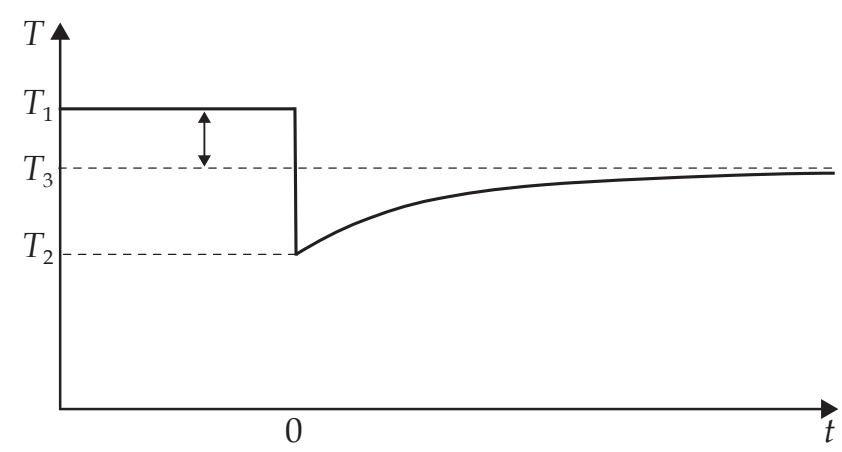

Figure 11. Graphical representation of Laffer curve for lower tax rates in coordinates 'tax revenues - time' included tax migration factor

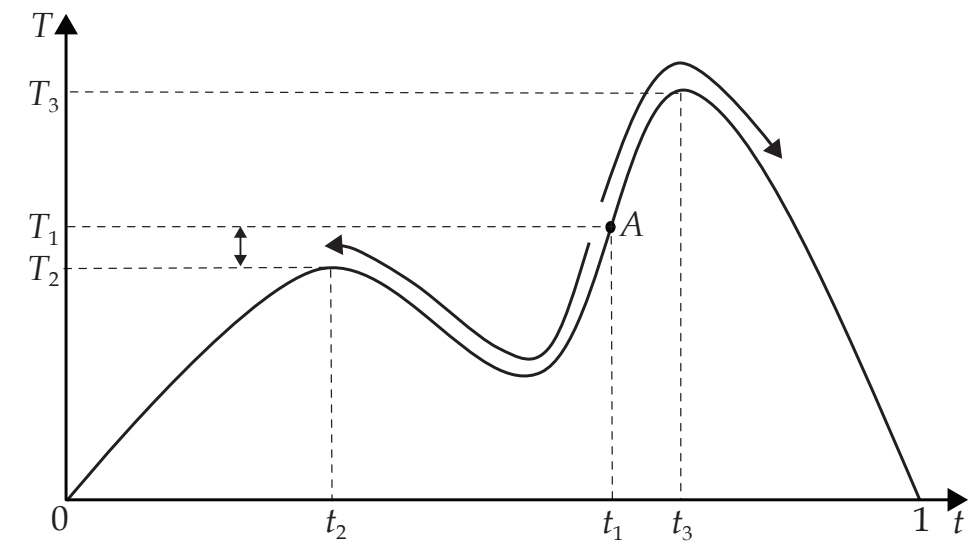

Figure 12. Graphical representation of Laffer curve included tax migration factor 


\section{Conclusion}

When carrying out tax reforms in a country, governments must start by empirically calculating a range of recommended changes to the tax burden. A properly implemented tax policy (that implies adjustments to taxation within the established corridor) might result in higher tax revenues: if tax rates are increased, the growth will occur immediately; if tax rates are lowered, the growth will occur after a certain period of time.

The main outcome of this research is a conclusion that lower rates of individual taxes will under no circumstances lead to a matching increase in tax revenues because of tax residents' compulsion to buy foreignmade goods and to make money abroad. Making the tax climate milder in the hope of recovering revenue shortfalls after a certain number of years will prove unproductive. Introducing taxpayer-friendlier rates only makes sense for the sake of stimulating their business activity, i.e. for the sake of business support rather than more government revenue should be the ultimate goal of undertaking tax liberalization. That might in fact be the answer to the question as to why the application of Laffer's concept in the USA and Europe in various times fell short of fiscal expectations.

\section{References}

1. Laffer A., Meiselman D. The phenomenon of worldwide inflation. American Enterprise Institute for Public Policy Re, 1975. 218 p.

2. Wanniski J. Taxes, Revenues, and the «Laffer Curve». The Public Interest, 1978, vol. 50, pp. 3-16.

3. Movshovich S. M., Sokolovsky L. E. Issue, taxes and the Laffer curve. Ekonomika $i$ matematicheskie metody = Economics and Mathematical Methods, 1994, vol. 30, no. 3, pp. 129-141. (In Russ.).

4. Bukach B. A. Justification and analysis of various variants of graphical interpretation of the Laffer curve. Vestnik Severo-Kavkazskogo gosudarstvennogo tekhnicheskogo universiteta. Seriya: Ekonomika i finansy = Bulletin of North-Caucasian STU. Series of economics and finance, 2012, vol. 130, pp. 30-38. (In Russ.).

5. Gutmann P. The Subterranean Economy. Financial Analysis Journal, 1977, vol. 33, no. 6, pp. 26-34.

6. Becsi Z. The shifty Laffer curve. Federal Reserve Bank of Atlanta. Economic review, 2000, vol. 85, no. 3, pp. 53-64.

7. Kakaulina M. O., Tsepelev O. A. Modelirovanie vliyaniya nalogovoi nagruzki na ekonomicheskii rost regiona s uchetom resursnogo potentsiala [Modeling the impact of taxes on economic growth with regional resource potential]. Vladivostok, Dal'nauka Publ., 2014. 428 p.

8. Henderson D. Limitation of the Laffer curve as a justification for tax cuts. Cato Journal, 1981, vol. 1, no. 1, pp. 45-52.

9. Gardner M. Mathematical games. The Laffer curve and the other laughs in current economics. Scientific American, 1981, vol. 245, pp. 18-31.

10. Kazman S. Exploring the Laffer curve: behavioral responses to taxation. UVM Honors College Senior Theses, 2014. 76 p.

11. Balatsky E. V. The Laffer points and their quantification. Mirovaya ekonomika i mezhdunarodnye otnosheniya $=$ World Economy and International Relations, 1997, no. 12, pp. 85-94. (In Russ.).

12. Laffer A., Seymour J. The economics of the tax revolt. Laffer. Harcourt Brace Jovanovich, 1979. $138 \mathrm{p}$.

13. Volobuev V. P. The Laffer points and their quantification. Mirovaya ekonomika i mezhdunarodnye otnosheniya = World Economy and International Relations, 1984, no. 11, pp. 119-125. (In Russ.).

14. Balatsky E. V. On the nature of the insolvency of the Russian fiscal system. Obshchestvo i ekonomika, 2004, no. 11-12, pp. 127-136. (In Russ.).

15. Mayburov I. A., Sokolovskaya A. M. Teoriya nalogooblozheniya: prodvinutyi kurs [Theory of taxation: advanced course]. Moscow, YuNITI-DANA Publ., 2011. 591 p.

16. Buchanan J., Lee D. Politics, time and Laffer curve. Journal of Political Economy, 1982, vol. 90, no. 4, pp. 816-819.

17. Buryak P. Yu., Londar S. L. The impact of the tax rate on budget revenues. Finansy Ukrainy = Finance of Ukraine, 2002, no. 1, pp. 41-44. (In Russ.). 
18. Vishnevsky V. P., Lipnitsky D. V. Assessment of the possibilities of reducing the tax burden in the transition economy. Voprosy ekonomiki = Issues of economics, 2000, no. 2, pp. 107-116. (In Russ.).

19. Ananiashvili Yu. Sh., Papava V. G. Nalogi i makroekonomicheskoe ravnovesie: laffero-keinsianskii sintez [Taxes and macroeconomic equilibrium: laffero-keynesian synthesis]. Stockholm, SA \& SS Press, 2010. 142 p.

20. Tsepelev O. A., Kakaulina M. O. Predicting the taxation burden of a region with the account of investment projects. Aktualnye problemy ekonomiki i prava $=$ Actual Problems of Economics and Law, 2012, no. 2, pp. 147-151. (In Russ.).

\section{Authors}

Maria O. Kakaulina - PhD in Economics, Associate Professor, Department of Finance, Amur State University, Blagoveshchensk, Russia (21 Ignatyevskoye Shosse, Blagoveshchensk, Amur Region, Russia 675027); ORCID: 0000-0002-2148-6236; e-mail: beuty1@mail.ru

\section{Информация об авторах}

Какаулина Мария Олеговна - кандидат экономических наук, доцент, кафедра финансов, Амурский государственный университет, г. Благовещенск, Россия (675027, Амурская область, г. Благовещенск, Игнатьевское шоссе, 21); ORCID: 0000-0002-2148-6236; e-mail: beuty1@mail.ru

\section{For citation}

Kakaulina M. O. Visual Representation of Laffer Curve Factoring in Implications of Capital Outflow. Journal of Tax Reform, 2017, vol. 3, no. 2, pp. 103-114. DOI: $10.15826 /$ itr.2017.3.2.034

\section{Аия цитирования}

Какаулина М. О. Визуализация кривой Лаффера с учетом последствий оттока капитала за рубеж / М. О. Какаулина // Journal of Tax Reform. - 2017. - T. 3, № 2. - C. 103-114. - DOI: 10.15826/jtr.2017.3.2.034

\section{Article info}

Received May 28, 2017; accepted July 4, 2017

\section{Информация о статье}

Дата поступления 28 мая 2017 г.; дата принятия к печати 4 июля 2017 г. 